\title{
Accidental injection of epinephrine by a child: a unique approach to treatment
}

\author{
Catharine Sellens, MD, Laurie Morrison, MD
}

\begin{abstract}
A 9-year-old girl accidentally injected her right thumb with an adult dose of epinephrine through an auto-injector syringe, delivering $0.3 \mathrm{mg}$ of $1: 1000$ epinephrine. This injection caused immediate ischemic changes in the digit. This is the first reported case of accidental self injection by a child of an adult dose of epinephrine and its successful treatment with low-dose phentolamine simultaneously infiltrated directly into the puncture area and along the course of the digital artery. The use of phentolamine as a specific competitive alpha-adrenergic antagonist to epinephrine has been well documented in adults and animal models. This report compares the management of a pediatric case to that of all reported adult cases of accidental subcutaneous epinephrine injections. This case suggests a pattern of infiltration with low-dose phentolamine that may be the most effective form of treatment for this condition in a patient of any age.

RÉSUMÉ ANALYTIQUE : Une fillette de 9 ans s'injecte accidentellement 0,3 mg d'épinéphrine 1:1 000 (une dose pour adulte) dans le pouce droit avec une seringue à auto-injecteur. Cette injection provoque des changements ischémiques immédiats dans le doigt. II s'agit du premier cas signalé d'auto-injection accidentelle d'une dose pour adulte d'épinéphrine chez un enfant. Elle est traitée avec succès grâce à une faible dose de phentolamine infiltrée simultanément au site de l'injection et tout au long de l'artère digitale. Le recours à la phentolamine comme bloqueur alpha-adrénergique concurrentiel spécifique de l'épinéphrine a été bien documenté chez les adultes et les modèles animaux. Ce rapport compare le traitement d'un cas pédiatrique avec tous les cas d'injections sous-cutanées accidentelles signalées chez les adultes. Cette observation suggère que l'infiltration d'une faible dose de phentolamine est peut-être la forme de traitement la plus efficace pour cette condition chez les patients de tous âges.
\end{abstract}

\section{Introduction}

The use of epinephrine auto-injectors for prehospital treatment of severe allergic reactions in children and adults has become increasingly more common. ${ }^{1,2}$ Several authors ${ }^{1-5}$ have reported the use of phentolamine to reverse the effects of subcutaneous extravasation of sympathomimetic agents or accidental epinephrine auto-injection in adults and animal models. In these cases, phentolamine was infiltrated locally at the site of puncture or along the course of the digital artery, but never both sites simultaneously. The phentolamine doses used ranged from 1.0 to $10.0 \mathrm{mg}$, with response times of 20 to 60 minutes. ${ }^{2,46}$ We present the first report of accidental injection of epinephrine into a digit by a child. We discuss the successful treatment of this case with half the minimum dose of phentolamine previously reported, which was administered simultaneously at the puncture site and along the course of the digital arteries.

\section{Case report}

A 9-year-old girl accidentally punctured her right thumb with an adult auto-injector epinephrine syringe. She had been inspecting the EpiPen ${ }^{\circledast}$ syringe (Allerex Laboratory Ltd., Kanata, Ont.) when it accidentally discharged, injecting a dose of $0.3 \mathrm{mg}$ of 1:1000 epinephrine into the volar pad of her right thumb. The epinephrine auto-injector had been prescribed for an adult family member the previous 
summer because of a severe allergic reaction to a wasp sting, and had not been used since that incident.

The patient arrived at the emergency department within 10 minutes of the injection. Her main complaints were pain, tingling, blanching and coldness of the digit. Her medical history was unremarkable for any known drug allergies or

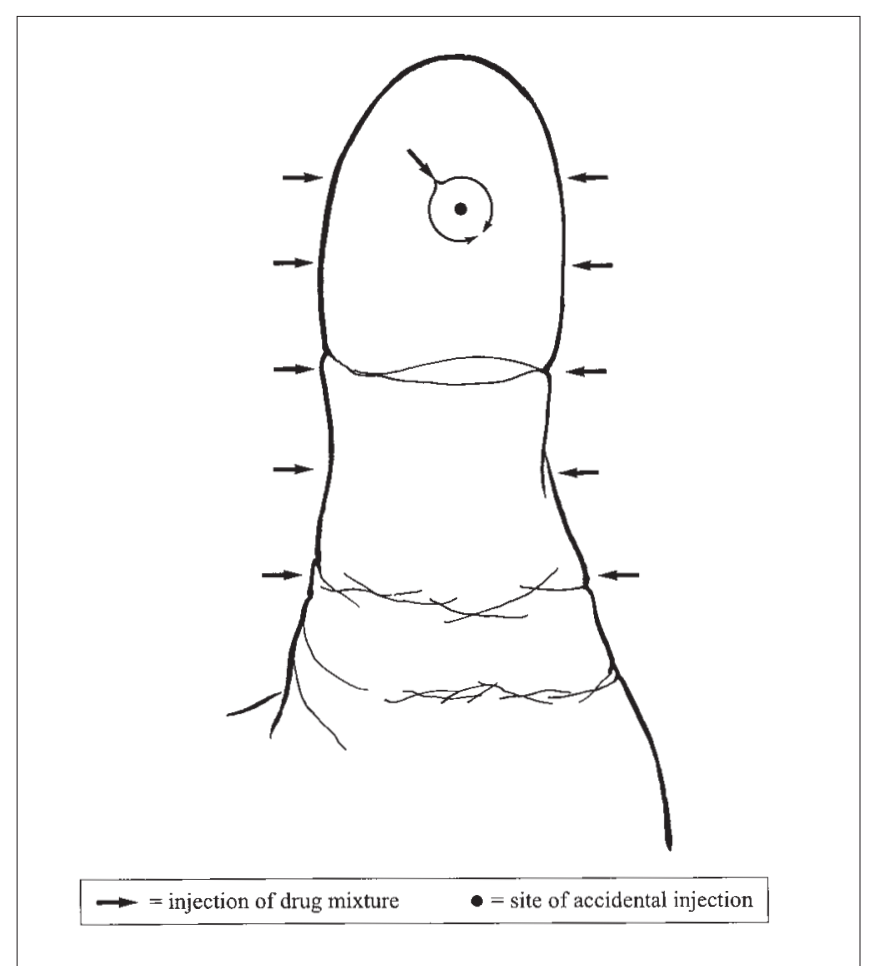

Fig. 1. Phentolamine was administered equitably using the injection pattern outlined in this figure. asthma. On examination, her heart rate was 88 beats/min and regular. Examination of the right thumb revealed a puncture wound centrally on the volar pad. The nail bed was noticeably blanched. The patient still retained pin-prick sensation with full active and passive range of motion. The attending physician confirmed the complete automatic injection of the contents of the syringe.

Initially $2.5 \mathrm{~cm}$ of nitroglycerin paste was applied over the thumb, but after 45 minutes there was no clinical improvement; therefore, a mixture of $0.5 \mathrm{mg}$ of phentolamine, $1.0 \mathrm{~mL}$ of normal saline and $1.0 \mathrm{~mL}$ of $2 \%$ lidocaine was prepared. Half of this mixture was infiltrated subcutaneously at the puncture site, and the rest was infiltrated along the course of the digital arteries (Fig. 1).

Within 5 minutes, sensation, colour, temperature and capillary refill returned to normal, and the pain dissipated. Vital signs remained stable throughout. This 9-year-old patient tolerated the series of infiltrations surprisingly well. Upon questioning, she said that the discomfort was minimal. She was symptom-free with no adverse long-term sequelae at 6 weeks after the injury.

\section{Discussion}

Epinephrine, a catecholamine, acts as a sympathomimetic agent and produces both $\alpha$-adrenergic and $\beta$-adrenergic responses. ${ }^{7.8}$ Increasingly, epinephrine is being used to treat anaphylaxis from insect bites and stings, as well as anaphylaxis of undetermined origin. ${ }^{1}$ Spring-loaded epinephrine administration devices provide an effective and rapid method

\begin{tabular}{|c|c|c|c|c|c|}
\hline Authors & Site & Age, yr & $\begin{array}{c}\text { Amount, } \\
\text { mg }\end{array}$ & Route & $\begin{array}{l}\text { Recovery time } \\
\text { min }\end{array}$ \\
\hline \multirow[t]{2}{*}{ Burkhart $^{13}$} & \multirow[t]{2}{*}{ Thumb } & \multirow[t]{2}{*}{40} & 0.5 & Digital block & No response \\
\hline & & & 2.5 & Digital block & 61 \\
\hline Deshmukh and Tolland ${ }^{3}$ & Finger & 39 & 1.0 & Local & 30 \\
\hline Hinterberger and Kintzi & Thumb & 17 & 10.0 & $\begin{array}{l}\text { Local/line } \\
\text { of demarcation }\end{array}$ & 60 \\
\hline \multirow[t]{2}{*}{ Maguire and Reisdorff ${ }^{1}$} & \multirow[t]{2}{*}{ Finger } & \multirow[t]{2}{*}{17} & 0.5 & Digital block & No response \\
\hline & & & 0.5 & Digital block & 30 \\
\hline \multirow[t]{2}{*}{ Markovchick and Burkhart ${ }^{14}$} & \multirow[t]{2}{*}{ Thumb } & \multirow[t]{2}{*}{30} & 2.5 & Digital block & No response \\
\hline & & & 1.0 & Local & 105 \\
\hline McCauley et $\mathrm{al}^{5}$ & Finger & 28 & 1.5 & Local & 20 \\
\hline Mol and Gaver ${ }^{6}$ & Finger & 39 & 1.0 & Local & 25 \\
\hline Roberts and Krisanda ${ }^{4}$ & $\begin{array}{l}\text { Brachial } \\
\text { artery }\end{array}$ & 45 & 5.0 & Intra-arterial & 20 \\
\hline Current case & Thumb & 9 & 0.5 & See Fig. 1 & 5 \\
\hline
\end{tabular}


of administration for allergic patients. These devices are specially designed to be used by individuals without medical training, who may not be able to inject themselves or others by conventional methods. ${ }^{6}$ Accidental epinephrine injections have an estimated incidence of 1 per 50000 units. $^{1}$

The accidental exposure in this report is similar to many adult cases reported in the literature. The injector fully discharged into the pulp of the child's thumb, and within minutes ischemic effects were observed. As in other reported human and animal cases, ${ }^{9}$ topical nitroglycerin paste failed to reverse these effects.

A review of the literature supports the safety and efficacy of phentolamine to reverse the effects of subcutaneous catecholamine extravasation. ${ }^{10,11}$ Case reports of adults and animal models show that phentolamine reverses ischemic effects and prevents skin necrosis after subcutaneous injection of epinephrine and other sympathomimetic agents. ${ }^{9,12}$

This case is unique in many ways. The dose of phentolamine used was $0.5 \mathrm{mg}$, half the minimum dose previously reported (Table 1). Despite this, recovery time was shorter than in previously published cases, and after our first set of infiltrations there was no need to reinject the digit. Several authors ${ }^{1-6,13,14}$ have reported infiltrating epinephrine puncture sites locally or performing phentolamine digital blocks. In some of these cases, ${ }^{1,13,14}$ a poor response necessitated additional infiltrations along the digital artery or around the puncture site.

The pattern of phentolamine infiltration shown in Fig. 1 has not been reported previously. In this case it led to rapid and complete resolution of symptoms after a single set of infiltrations, sparing our patient a subsequent set. This is advantageous in children, since it may be challenging to convince younger children of the need for additional injections. Further, it is possible that this method of administration may reduce the amount of drug required to reverse ischemic effects, thereby providing a greater margin of safety and reducing the risk of pressure necrosis or compartment syndrome that may occur when a large volume of drug is infiltrated into the pulp space of a digit. In this case, as in all other reported cases, there were no adverse effects associated with phentolamine infiltration.

\section{Conclusions}

This case of accidental epinephrine injection into a thumb by a child, was successfully treated by infiltrating $0.5 \mathrm{mg}$ of phentolamine directly into the puncture area and along the course of the digital artery simultaneously. This pattern of infiltration has not been reported previously and may be responsible for the rapid recovery and the low dose of phentolamine required to reverse digital ischemia. We believe it may be the most effective method of treatment for subcutaneous digital catecholamine exposures in patients of any age.

\section{References}

1. Maguire WM, Reisdorff MD. Epinephrine-induced vasospasm reversed by phentolamine digital block. Am J Emerg Med 1990;8:46-7.

2. Hinterberger JW, Kintzi HE. Phentolamine reversal of epinephrine-induced digital vasospasm. Arch Fam Med 1994;3:193-5.

3. Deshmukh N, Tolland JT. Treatment of accidental epinephrine injection in a finger [letter]. J Emerg Med 1989;7(4):408.

4. Roberts JR, Krisanda TJ. Accidental intra-arterial injection of epinephrine treated with phentolamine. Ann Emerg Med 1989;18:424-5.

5. McCauley WA, Gerace RV, Scilley C. Treatment of accidental digital injection of epinephrine. Ann Emerg Med 1991;20:665-8.

6. Mol CJ, Gaver J. A 39-year-old nurse with accidental discharge of an epinephrine autoinjector into the left index finger. J Emerg Nurs 1992;18:306-9.

7. Weiner N. Alpha-adrenergic blocking agents. In: Gilman AG, Goodman LS, Rall TW, Hardman JG, Limbird LE, Molinoff PB, et al, editors. The pharmacologic basis of therapeutics, 9th ed. New York: Macmillan Publishing Co.; 1996. p. 221-43.

8. Johnson HA. Infiltration with epinephrine and local anesthetic mixture in the hand. JAMA 1967;200:990-1.

9. Aycock BG, Hawtof DB, Moody SB. Treatment of peripheral ischemia secondary to lidocaine containing epinephrine. Ann Plast Surg 1989;23:27-30.

10. Richards DA, Woodings EP, Prichard BNC. Circulatory and alpha-adrenoceptor blocking effects of phentolamine. Br J Clin Pharmacol 1978;5:507-13.

11. Coffman JD, Cohen RA. Intra-arterial vasodilator agents to reverse human finger vasoconstriction. Clin Pharmacol Ther 1987;41:574-9.

12. Zucker G. Use of phentolamine to prevent necrosis due to levarterenol. JAMA 1957; 163:1477-9.

13. Burkhart KK. The reversal of the ischemic effects of epinephrine on a finger with local injections of phentolamine [letter; comment]. J Emerg Med 1992;10(4):496. Comment in: J Emerg Med 1991;9(5):323-4.

14. Markovchick V, Burkhart KK. The reversal of the ischemic effects of epinephrine on a finger with local injections of phentolamine [see comment]. J Emerg Med 1991;9(5):323-4. Comment in: J Emerg Med 1992;10(4):496.

Correspondence to: PHC.research@utoronto.ca

Editor's Note: Although these authors specifically address the issue of epinephrine-injector injury, the therapy they describe is probably widely applicable to patients who undergo inadvertent digital injection of local anesthetic with epinephrine, which is a much more frequent $\mathrm{ED}$ occurrence.[G.I.] 